\title{
Characterization of Nutritional and Process Quality of Some Faba Bean Varieties and Advanced Lines Grown at Bale, South Eastern Oromia
}

\author{
Shure Soboka ${ }^{1, *}$, Tadele Tadesse ${ }^{2}$, Amanuel Tekalgn $^{2}$ \\ ${ }^{1}$ Oromia Agricultural Research Institute, Addis Ababa, Ethiopia \\ ${ }^{2}$ Sinana Agricultural Research Center, Bale-Robe, Ethiopia
}

Email address:

ibsasoboka2020@gmail.com (S. Soboka)

*Corresponding author

To cite this article:

Shure Soboka, Tadele Tadesse, Amanuel Tekalgn. Characterization of Nutritional and Process Quality of Some Faba Bean Varieties and Advanced Lines Grown at Bale, South Eastern Oromia. Bioprocess Engineering. Vol. 5, No. 1, 2021, pp. 11-16.

doi: $10.11648 /$ j.be. 20210501.12

Received: October 30, 2020; Accepted: May 13, 2021; Published: June 4, 2021

\begin{abstract}
Faba bean is said to be poor man's meat as it is the most important protein source for most of world's population. Field experiment was carried out at Sinana and sinja site if Goba districts of Bale highland to see the effect of faba bean genotypes and growing environment on some physico-chemical and nutritional qualities of faba bean genotypes. For this experiment, fifteen faba bean genotypes including released and promising lines were evaluated for their physico-chemical quality characterization. From the result it was seen that most quality characters measured have shown significant variation $(\mathrm{p}<0.05)$ due to faba bean genotypes. The nutrient contents of the grains of the test genotypes across two testing environments, crude protein vary from (22.43-24.34\%), phosphorous (0.62-0.70\%), sodium (405-262.31 ppm), potassium (1.77-1.40 $\mathrm{gm} / 100 \mathrm{gm})$, calcium $(932.08-830.32 \mathrm{ppm})$ and hydration potential vary from $(2.12$ to $2.04 \%)$ which fall under high to sufficient nutrient content when compared to nutrient composition of plant material. Genotypes EH07006-51, EH070015-7, EH07006-1 and EH0773-8 have got better quality characters as compared to the released varieties Shallo, Mosisa and the local check. Genotype EH07006-1 is better in percent hydration, Na and K composition as compared to the other test genotypes. From the collected data it is possible to conclude that genotypes EH07006-1, EH07006-51, EH070015-7 and EH0773-8 are better to be selected for the variety verification.
\end{abstract}

Keywords: Faba Bean, Nutritional Quality, Protein Content

\section{Introduction}

Faba bean (Viciafabae L.) is one of the earliest domesticated food legumes in the world, probably in the late Neolithic period [1]. It is believed that the crop was introduced to Ethiopia from the Middle East via Egypt around 5000 B. C., immediately after its domestication [2] Ethiopia is now considered as one of the centers of secondary diversity for faba bean [3] where it is mainly used as human food. Globally, faba bean is the fourth major cool-season pulse crop in terms of total production after chickpea (Cicerarietinum L.), field pea (Pisum sativum L.) and lentil (Lensculinaris L.) [4, 5]. China has been the main producing country, followed by Ethiopia, Egypt, Italy, and
Morocco. Even though Ethiopia is the world's second largest producer of faba bean, its share is only $21.03 \%$ of world production and $40.5 \%$ within Africa [6]. In Ethiopia, the crop occupies the largest area among the pulses and was grown on 0.43 million ha of land with the total yield 0.88 million tons and an average yield of $2.05 \mathrm{t} \mathrm{ha}^{-1}$ [7], but production is not adequate enough to meet local demand and satisfy lucrative export markets in Sudan, Egypt and elsewhere. While world average grain yield of faba bean is around $1.81 \mathrm{t} \mathrm{ha}^{-1}$. [8].

The crop plays an important role in global human diet and agriculture [9] where Ethiopia is among the major faba beanproducing countries in the world ranking second next to China. In the country, faba bean is grown primarily for its 
edible seeds that are used for human consumption. The mature seeds can be eaten fresh or cooked in different forms such as: steaming, roasting, frying and other most common cooking methods similar to other legumes [10] Faba bean grain is high in protein (28-32\%) compared to field peas $(24 \%)$ and are low in oil. It is also rich in minerals such as calcium, phosphorus as well as vitamins even though there is slight variation among varieties [11].

The major aim for any crop breeding program is the development of good quality lines with an adequate resistance/tolerance to yield-reducing stresses [12]. In Ethiopian faba bean breeding program, grain yield, disease resistance and in some cases, protein content is the only quality parameter to be evaluated for the release of improved variety even though the country is the second largest in releasing improved faba bean varieties. As a result nutritional quality reports are available only for a few faba bean cultivars released so far. So, scientific justification of food quality of improved as well as advanced lines of faba bean, is very important. Therefore, this study was conducted with the objectives to characterize physicochemical and nutritional qualities of released as well as promising faba bean genotypes grown in bale highlands of Oromia.

\section{Materials and Methods}

\subsection{Experimental Design}

Fifteen faba bean genotypes including released and advanced line were collected from Sinana Agricultural Research Center from crop grown under Sinana and Goba districts of Bale highlands in 20016/17 cropping season. The collected samples were cleaned, milled and made to pass through $1 \mathrm{~mm}$ sieve and made ready for laboratory analysis. Quality assessment was carried out at Oromia Agricultural Research Institute (IQQO) Food Science Research Laboratories.

\subsection{Data on Processing Quality}

Initial weight of solids (IWS) (g): Determined as a loss in moisture by drying 150 grams of bean sample at $60^{\circ} \mathrm{C}$ for 24 hours in an oven [13]. Water absorption (WA): A sample of 150 gram $\left(\mathrm{W}_{1}\right)$ of raw beans was soaked at room temperature $\left(25^{\circ} \mathrm{C}\right)$ in distilled water $(1: 5 \mathrm{~W} / \mathrm{V})$. After $16 \mathrm{~h}$, the soaked bean was removed from the soaking water, drained, surface dried with lint free filter paper, and reweighed $\left(\mathrm{W}_{2}\right)$. From the weight difference, WA was expressed as percentage increase of the seed weight [14]. From the result, hydration ratio (HR) was computed as weight of soaked beans $\left(\mathrm{W}_{2}\right)$ divided by initial weight $\left(\mathrm{W}_{1}\right)$ [13].

\subsection{Data on Bean Chemical Composition}

\subsubsection{Ash Content}

The ash content was determined gravimetrically in accordance to [15] method 08-01. About 3g of flour sample was weighed on a pre- ignited and cooled procaine crucible. Ashing of the sample was done in a muffle furnace adjusted to $550^{\circ} \mathrm{C}$ for three hours. After cooling in desiccators, $\%$ ash was calculated from the mass difference on dry matter basis.

\subsubsection{Crude protein Content}

Crude protein content was determined by the microKjeldahl procedure by taking about $0.5 \mathrm{~g}$ flour samples using a $\mathrm{K}_{2} \mathrm{SO}_{4}-\mathrm{CuSO}_{4}$ catalyst in according to [15] method 46-12.

\subsubsection{Mineral Content}

The mineral content of faba bean samples was determined by using the method described by [16]. The ash obtained from the ash analysis earlier was used in the determination of the minerals content. The ash was placed in porcelain crucibles, and dissolved with few drops of distilled water, followed by $5 \mathrm{ml}$ of $2 \mathrm{~N}$ hydrochloric acid and filtered through Whiteman filter paper into $100 \mathrm{ml}$ volumetric flask. The minerals such as calcium $(\mathrm{Ca})$, Sodium $(\mathrm{Na})$ and Potassium (K) was then determined by using Flame photometer while phosphorous (P) content was determined using spectrophotometer and the obtained results were adjusted at $12.5 \%$ moisture bases.

\subsection{Statistical Analysis}

All data collected was subjected to the (ANOVA) using SAS GLM procedure [17]. The significance between mean values (mean separation) was expressed by Least Significant difference (LSD) method.

\section{Results and Discussion}

Combined analysis results indicated out of the physicochemical quality characters evaluated, protein and initial weight of solids are non-significantly varied due to genotypes $(\mathrm{P}>0.05)$ (Table 1 and 2 ). Hydration potential varied from the highest 2.12 genotype EH07006-1 to the lowest 2.04 variety Shallo. The higher hydration potential of all the test genotypes mean each grain of faba bean can absorb twice of its initial weight. High hydration coefficient indicates that the seeds are capable of imbibing water efficiency after soaking and it is valuable quality factor for a consumer which correlates positively with cookability. This indirctly mean high flour yield would be obtained from the test genotypes. According to [18], genotype with higher water absorption would have longer cooking time as more time is needed for the water to be absorbed into the bean. Thousand kernel weight $(\mathrm{TKW})$ of the genotypes varied significantly $(\mathrm{P}<0.05)$ from the highest 937.70 for the genotype -EH070015-7 to the smallest 580.02 for the local cultivar. TKW is indirectly related to kernel size. According to [19] the TKW of faba bean genotypes grown at Nubaria Research Station, Egypt, varied from 1092 to $1187 \mathrm{gm} / 1000$ grains. Accordingly, the TKW of faba bean genotypes in the current study $20 \%$, medium size, $47 \%$ large and $33 \%$ of them fall under very large size grains [20] (Tables 1 and 2).

Pulse crops are mainly consumed for their protein content. Therefore, irrespective of the form of consumption, protein content and other important nutritional characteristics must 
be safeguarded and improved [21]. Ash, which is the direct indicator of the mineral content and the inorganic residue that remains after burning the organic matter varied significantly $(\mathrm{P}<0.05)$ from 2.27 for genotype $(\mathrm{EH} 07003-11)$ to $2.16 \%$
(Mosisa). Findings of different researchers [22, 23], the ash content of faba bean genotypes varied from 2.65 to $3.6 \%$ which is slightly higher as compared to result of the current study.

Table 1. Mean physico-chemical quality characters of faba bean genotypes combined over location

\begin{tabular}{|c|c|c|c|}
\hline Genotypes & Initial wt/150gm & MC & Hydration Potential \\
\hline EH070013-7 & $137.96 \pm 0.49$ & $9.07 \pm 0.53^{\mathrm{ab}}$ & $2.08 \pm 0.03^{\mathrm{abc}}$ \\
\hline ЕH070024-3 & $137.33 \pm 0.97$ & $9.11 \pm 0.88^{\mathrm{ab}}$ & $2.07 \pm 0.01^{\mathrm{abc}}$ \\
\hline ЕН070015-7 & $137.59 \pm 0.05$ & $9.32 \pm 0.35^{\mathrm{a}}$ & $2.05 \pm 0.01^{\mathrm{bc}}$ \\
\hline ЕH07006-1 & $137.38 \pm 0.99$ & $8.87 \pm 0.60^{\mathrm{ab}}$ & $2.12 \pm 0.01^{\mathrm{a}}$ \\
\hline ЕH0773-8 & $137.29 \pm 0.46$ & $9.07 \pm 0.37^{\mathrm{ab}}$ & $2.07 \pm 0.03^{\mathrm{abc}}$ \\
\hline ЕН07006-51 & $138.07 \pm 0.23$ & $9.07 \pm 0.53^{\mathrm{ab}}$ & $2.10 \pm 0.06^{\mathrm{abc}}$ \\
\hline EK02019-2 & $137.47 \pm 1.10$ & $9.14 \pm 0.31^{\mathrm{ab}}$ & $2.11 \pm 0.01^{\mathrm{ab}}$ \\
\hline EK02017-3 & $137.91 \pm 0.40$ & $9.16 \pm 0.38^{\mathrm{ab}}$ & $2.10 \pm 0.02^{\mathrm{abc}}$ \\
\hline EH00100-3 & $137.63 \pm 1.56$ & $8.78 \pm 0.51^{\mathrm{b}}$ & $2.10 \pm 0.03^{\mathrm{abc}}$ \\
\hline EH06007-2 & $136.95 \pm 0.73$ & $9.32 \pm 0.33^{\mathrm{a}}$ & $2.10 \pm 0.04^{\mathrm{abc}}$ \\
\hline Mosisa & $137.00 \pm 0.36$ & $9.08 \pm 0.46^{\mathrm{ab}}$ & $2.06 \pm 0.04^{\mathrm{bc}}$ \\
\hline Shallo & $137.02 \pm 0.76$ & $9.06 \pm 0.60^{\mathrm{ab}}$ & $2.04 \pm 0.00^{\mathrm{c}}$ \\
\hline Local Ckeck & $136.59 \pm 0.53$ & $9.10 \pm 0.35^{\mathrm{ab}}$ & $2.05 \pm 0.02^{\mathrm{bc}}$ \\
\hline Mean & $137.41 \pm 0.68$ & $9.08 \pm 0.49$ & $2.08 \pm 0.03$ \\
\hline $\operatorname{LSD}(<0.05)$ & 0.56 & 0.47 & 0.063 \\
\hline
\end{tabular}

Values with different letter within a column are significantly different $(\mathrm{p}<0.05)$, MC=Moisture Content $(\%)$, CV=Coefficient of variation, LSD=Least Significance difference

In this study, the protein contents of test genotypes varied from 22.43 to $24.34 \%$, which is in similar range with bean germplasm accessions analyzed for protein content, and ranged from 17 to $28 \%$, while the average being around $23.26 \%$ [24]. The highest \%CP value was recorded for genotype EH07006-51 followed by genotype EH07003-11, whiles the lowest for the released variety Shallo (Table 2). Result by [24] (Fatemeh, et al., 2018) indicated the protein content of six faba bean varieties vary from 16.94 to $21.69 \%$.
According to [25], the protein content of Vicia faba (V. faba; faba bean) ranges from 26 to $41 \%$ which have slight variation. From the result it is seen that even though there is significant variation among the protein contents of the genotypes under this study, there is no large difference in protein composition. It is known that protein content is highly affected by growing environment and crop management. But genetic factor do have higher influence.

Table 2. Mean physico-chemical quality characters of faba bean genotypes combined over location

\begin{tabular}{|c|c|c|c|}
\hline Genotypes & $\%$ ash & $\% \mathrm{CP}$ & TKW \\
\hline EH070013-7 & $2.35 \pm 0.18 \mathrm{~cd}$ & $22.89 \pm 1.35$ & $705.49 \pm 151.68^{\mathrm{e}}$ \\
\hline ЕН070024-3 & $2.42 \pm 0.26 \mathrm{c}$ & $23.88 \pm 0.93$ & $844.67 \pm 22.67 b^{c}$ \\
\hline ЕН070015-7 & $2.68 \pm 0.13 \mathrm{abc}$ & $23.64 \pm 1.29$ & $937.70 \pm 35.29^{\mathrm{a}}$ \\
\hline ЕН070023-6 & $2.44 \pm 0.26 b c$ & $23.15 \pm 1.74$ & $774.53 \pm 41.14^{\mathrm{d}}$ \\
\hline ЕН07006-1 & $2.63 \pm 0.16 \mathrm{abc}$ & $22.89 \pm 1.18$ & $672.38 \pm 37.21^{\mathrm{f}}$ \\
\hline ЕH0773-8 & $2.45 \pm 0.12 b c$ & $22.52 \pm 1.56$ & $581.80 \pm 162.84^{\mathrm{g}}$ \\
\hline ЕH07006-51 & $2.56 \pm 0.19 \mathrm{abc}$ & $24.34 \pm 1.60$ & $805.34 \pm 8.96^{\mathrm{cd}}$ \\
\hline EK02019-2 & $2.02 \pm 0.51 \mathrm{~d}$ & $23.92 \pm 1.42$ & $899.38 \pm 55.45^{\mathrm{ab}}$ \\
\hline EK02017-3 & $2.36 \pm 0.21 \mathrm{~cd}$ & $23.05 \pm 1.44$ & $887.72 \pm 19.10^{\mathrm{ab}}$ \\
\hline EH00100-3 & $2.54 \pm 0.27 \mathrm{abc}$ & $23.26 \pm 1.79$ & $883.45 \pm 12.92^{\mathrm{ab}}$ \\
\hline EH06007-2 & $2.84 \pm 0.49 \mathrm{a}$ & $22.92 \pm 1.81$ & $889.53 \pm 14.98^{\mathrm{ab}}$ \\
\hline Mosisa & $2.69 \pm 0.49 \mathrm{abc}$ & $23.19 \pm 2.83$ & $605.06 \pm 18.52^{\mathrm{fg}}$ \\
\hline Shallo & $2.79 \pm 0.56 \mathrm{ab}$ & $22.43 \pm 2.99$ & $591.98 \pm 10.48^{g}$ \\
\hline Local Ckeck & $2.86 \pm 0.54 \mathrm{a}$ & $22.63 \pm 2.29$ & $580.02 \pm 41.50^{\mathrm{g}}$ \\
\hline $\operatorname{LSD}(<0.05)$ & 0.37 & Ns & 68.65 \\
\hline
\end{tabular}

Values with different letter within a column are significantly different $(\mathrm{p}<0.05)$, TKW=thousand kernel weight $(\mathrm{gm}$.), $\mathrm{CP}=$ crude protein content, $\mathrm{N}=\mathrm{nitrogen}$ content, $\mathrm{CV}=$ Coefficient of variation, $\mathrm{LSD}=$ Least Significance difference

Mineral contents of faba bean genotypes are presented in Table 3. Calcium, potassium, and protein were presented in table 3. The combined results of minerals ( $\mathrm{Na}, \mathrm{K}, \mathrm{Ca}$ and $\mathrm{P}$ ) of the faba bean genotypes also shown significant variation $(\mathrm{P}<0.05)$. Genotype EK02017-3 got the highest $\mathrm{Na}(5.60$ ppm) content while the genotype EH070015-7 (405.02 ppm) 
followed by EH070013-7 (376.42ppm) with the lowest EH07006-51 (262.31 ppm). Potassium also varied from the lowest 1.40 to $1.77(\mathrm{gm} / 100 \mathrm{gm})$ for faba bean genotype EH070023-6 and Shallo respectively. Calcium content also varied from 932.08 for genotype EH0773-8 while the lowest 831.19 ppm for EK02019-2 genotype. The phosphorous content of the test genotypes also vary from the highest 0.70 $\mathrm{gm} / 100 \mathrm{gm}$ to $0.62 \mathrm{gm} / 100 \mathrm{gm}$ for faba bean genotype EH070023-6.

Faba beans are a good source of dietary minerals, such as phosphorus, potassium, calcium, sulphur and iron. Results from the study done by [26], Calcium content of faba bean varieties ranges from $0.09 \%$ dry mass bases, which is similar range with the result of the current study. According to [27], the mean phosphorous content of faba bean genotypes evaluated for antinutritional compound composition is $0.79 \%$ [28], and potassium content also have a mean result of $1.65 \%$, which is in similar range with the result of the current study. According to the study done by [29] the sodium content of faba bean genotypes found in similar range with two faba bean genotypes and vary from $30.49 \mathrm{mg} / 100 \mathrm{~g}$ to $25.85 \mathrm{mg} / 100 \mathrm{~g}$. According to [30] the nutrient contents of the grains of the test genotypes across two testing environments, crude protein, phosphorous, and nitrogen fall under high while potassium fall under sufficient and calcium under low content. (table 3). But faba bean genotypes EH070015-7, EH0773-8, EH07006-1 and EH07006-51 are better to be promoted to VVT. While faba bean variety shallo is better im most of quality characters evaluated.

Table 3. Chemical quality characters of faba bean genotypes combined over location

\begin{tabular}{|c|c|c|c|c|}
\hline Genotypes & Na ppm & $\mathrm{K}(\mathrm{gm} / 100 \mathrm{gm})$ & Ca ppm & $P(\mathrm{gm} / 100 \mathrm{gm})$ \\
\hline EH070013-7 & $345.78 \pm 111.22^{\mathrm{abc}}$ & $1.65 \pm 0.20^{\mathrm{ab}}$ & $880.63 \pm 329.97^{\mathrm{abc}}$ & $0.65 \pm 0.17^{\mathrm{abc}}$ \\
\hline ЕH070024-3 & $328.99 \pm 160.37^{\mathrm{abc}}$ & $1.55 \pm 0.13^{\mathrm{bc}}$ & $871.24 \pm 366.77^{\mathrm{abc}}$ & $0.66 \pm 0.16^{\mathrm{abc}}$ \\
\hline ЕН070015-7 & $405.02 \pm 160.12^{\mathrm{a}}$ & $1.52 \pm 0.13^{\mathrm{bc}}$ & $844.37 \pm 352.59^{\mathrm{bc}}$ & $0.63 \pm 0.16^{\mathrm{abc}}$ \\
\hline ЕH07006-1 & $287.11 \pm 127.94^{\mathrm{bc}}$ & $1.61 \pm 0.13^{\mathrm{ab}}$ & $853.56 \pm 333.44^{b c}$ & $0.66 \pm 0.16^{\mathrm{abc}}$ \\
\hline EH0773-8 & $352.76 \pm 105.13^{\mathrm{abc}}$ & $1.66 \pm 0.10^{\mathrm{ab}}$ & $932.08 \pm 408.62^{\mathrm{a}}$ & $0.69 \pm 0.18^{\mathrm{ab}}$ \\
\hline ЕH07006-51 & $262.31 \pm 75.87^{\mathrm{c}}$ & $1.53 \pm 0.07^{\mathrm{bc}}$ & $830.32 \pm 314.61^{c}$ & $0.62 \pm 0.14^{\mathrm{c}}$ \\
\hline EK02019-2 & $304.00 \pm 63.82^{\mathrm{bc}}$ & $1.51 \pm 0.08^{\mathrm{bc}}$ & $831.19 \pm 343.83^{c}$ & $0.63 \pm 0.21^{\mathrm{abc}}$ \\
\hline EK02017-3 & $376.42 \pm 140.68^{\mathrm{ab}}$ & $1.62 \pm 0.11^{\mathrm{ab}}$ & $894.41 \pm 343.91^{\mathrm{abc}}$ & $0.65 \pm 0.16^{\mathrm{abc}}$ \\
\hline EH00100-3 & $350.36 \pm 93.89^{\mathrm{abc}}$ & $1.65 \pm 0.06^{\mathrm{ab}}$ & $907.22 \pm 358.21^{\mathrm{ab}}$ & $0.63 \pm 0.13^{\mathrm{abc}}$ \\
\hline EH06007-2 & $348.42 \pm 132.66^{\mathrm{abc}}$ & $1.64 \pm 0.06^{\mathrm{ab}}$ & $917.42 \pm 403.22^{\mathrm{ab}}$ & $0.63 \pm 0.14^{\mathrm{bc}}$ \\
\hline Mosisa & $368.93 \pm 156.90^{\mathrm{ab}}$ & $1.64 \pm 0.12^{\mathrm{ab}}$ & $882.67 \pm 322.11^{\mathrm{abc}}$ & $0.66 \pm 0.20^{\mathrm{abc}}$ \\
\hline Shallo & $384.59 \pm 146.23^{\mathrm{ab}}$ & $1.77 \pm 0.25^{\mathrm{a}}$ & $916.26 \pm 302.52^{\mathrm{ab}}$ & $0.70 \pm 0.22^{\mathrm{a}}$ \\
\hline Local Ckeck & $339.77 \pm 125.71^{\mathrm{abc}}$ & $1.64 \pm 0.15^{\mathrm{ab}}$ & $899.97 \pm 318.79^{\mathrm{abc}}$ & $0.68 \pm 0.23^{\mathrm{abc}}$ \\
\hline Mean & $338.25 \pm 122.28$ & $1.60 \pm 0.17$ & $880.89 \pm 321.00$ & $0.65 \pm 0.16$ \\
\hline $\operatorname{LSD}(<0.05)$ & 98.76 & 0.19 & 74.17 & 0.07 \\
\hline
\end{tabular}

Values with different letter within a column are significantly different $(\mathrm{p}<0.05), \mathrm{CV}=$ Coefficient of variation, LSD $=$ Least Significance difference, $\mathrm{P}=$ phosphorous content, $\mathrm{Na}=$ Sodium, $\mathrm{K}=$ Potassium, and $\mathrm{Ca}=$ Calcium content

Table 4. Different Nutrient contents of plant materials in \%.

\begin{tabular}{|c|c|c|c|c|}
\hline Nutrient & Deficient & Low & Sufficient & High \\
\hline Nitrogen \% & $<1.25$ & $1.25-1.74$ & $1.75-3.0$ & $>3.0$ \\
\hline Phosphorous \% & 0.15 & $0.15-0.19$ & $0.2-0.50$ & $>0.5$ \\
\hline Potassium \% & $<1.25$ & $1.25-1.49$ & $1.50-3.0$ & $>3.00$ \\
\hline Calcium \% & & $<0.20$ & $0.2-0.50$ & $>0.50$ \\
\hline Protein \% & $<7.51$ & $7.50-10.90$ & $10.90-18.75$ & $>18.80$ \\
\hline
\end{tabular}

Source: Walsh and Beaton (1963)

\section{Conclusion and Recommendations}

From the result, it was seen that most quality characters measured have shown significant variation due to faba bean genotypes and growing environment. Genotypes EH0700651, EH070015-7 and EH0773-8 and EH07006-1 have better quality characters as compared to the released varieties Shallo, Mosisa and the local check. Genotype EH07006-1 is better in percent hydration, $\mathrm{Na}$ and $\mathrm{K}$ composition as compared to the other test genotypes. From the collected data it is possible to conclude that genotypes EH07006-1, EH07006-51, EH070015-7 and EH0773-8 are better to be selected for the variety verification even-though data on cooking time, antinutritional factor and other agronomic and physiological data are not included. Finally, based on nutritional, process and physico-chemical quality characters evaluated across location, if the genotypes are stable across location and year physiologically, the above mentioned genotypes can be recommended. On the other hand, Shallo variety can be used for crossing purpose.

\section{Acknowledgements}

The authors are grateful to Oromia Agricultural Research 
Institute, Sinana Agricultural Research Center, AGP II donors and IQQO Food Science directorate staff in general for the financial support and facilitation of vehicle for this research work.

\section{References}

[1] Metayer 2004. Vicia faba breeding for sustainable agriculture in Europe. Gie feverole.

[2] Asfaw Telaye, Tesfaye Getachew and Beyene Demitsu. 1994. Genetics and breeding of faba bean. Pp.122-137. In: Asfaw Telaye (Eds). Cool-season food Legumes in Ethiopia. Proceedings: First National Cool-season Food legume Review Conference, Addis Ababa, Ethiopia.

[3] Torres, et al., 2006. Faba bean breeding for resistance against biotic stresses: Towards application of marker technology. Euphytica, pp. 147, 67-80.

[4] Rebaa F, Abid G, Aouida M, Abdelkarim S, Aroua I, Muhovski Y, Baudoin J-P, M'hamdi M, Sassi K, Jebara M (2017) Genetic variability in Tunisian populations of faba bean (Vicia faba L. var. major) assessed by morphological and SSR markers. Physiology and Molecular Biology of Plants 23, 397-409. doi: 10.1007/s12298-017-0419-x.

[5] Sallam A, Ghanbari M, Martsch R (2017) Genetic analysis of winter hardiness and effect of sowing date on yield traits in winter faba bean. Scientia Horticulturae 224, 296-301. doi: 10.1016/j.scienta.2017.04.015.

[6] Rawal, V. \& Navarro, D. K., eds. 2019. Food and Agriculture Organization the United Nations, Rome: The Global of Economy Pulses Rome.

[7] CSA (Centeral Statistical Authority), 2017. Agricultural Sample Survey 2016/2017. Report on Area and Production for Major Mrops: Private Peasant Holding 'Meher' Season. Statistical Bulletin 584. CSA, Addis Ababa, Ethiopia.

[8] Food and Agriculture Organization the United Nations, Rome: 2014. The Global of Economy Pulses Rome.

[9] Etemadi, F., M. Hashemi, O. Zandvakili, A. Dolatabadian, and A. Sadeghpour. 2018. Nitrogen contribution from winterkilled faba bean cover crop to spring-sown sweet corn in conventional and no-till systems. Agronomy Journal 110 (2): 455-462.

[10] Fabbri, A. D., \& Crosby, G. A. (2016). A review of the impact of preparation and cooking on the nutritional quality of vegetables and legumes. International Journal of Gastronomy and Food Science, 3, 2-11.

[11] Food and Agriculture Organization (FAO). (2019). FAOSTAT Statistical Database of the United Nation Food and Agriculture Organization (FAO) statistical division, Rome.

[12] Gutierrez, et. al. 2006. Markers to assist selection for low vicine and convicine contents in faba bean (Vicia faba L.). Theor. Appl. Genet., 114, 59-66.

[13] Ghaderi, A.; G. L. Hosfield; M. W. Adams and M. A. Uebersax, 1984. Variability in culinary quality, component interrelationships, and breeding implications in navy and pinto beans. Journal of American Society of Horticultural Sciences. 109 (1): 85-90.
[14] Martin-Cabrejes, M. A.; R. M Esteban; P. Perez; G. Maina and K. W. Waldron, 1997. Changes in physicochemical properties of dry beans (Phaseolus vulgaris L.) during longterm storage. Journal of Agricultural and Food Chemistry. 45: $3223-3227$

[15] AACC, 2000. Approved Methods of the American Association Cereal Chemists. American Association of Cereal Chemists. Inc., St. Paul, Minnesota.

[16] Association of Official Analytical chemists (AOAC) 1998. Official methods of Analysis of AOAC international. $16^{\text {th }}$ Edition. $4^{\text {th }}$ revision.

[17] SAS, 1998. Statistical analysis system (SAS) institute inc., Cary, NC, USA.

[18] Hosfield, G. L. and Uebersax, M. A., 1980. Variability in physiochemical properties and nutritional components of tropical and domestic dry bean germ plasm. Journal of American Society of Horticultural Sciences. 105: 246.

[19] Mona, A. M., Sabah, M. A., and Rehab, A. M. (2011). Influence of potassium sulfate on faba bean yield and quality. Aust. J. Basic Appl. Sci. 5, 87-95.

[20] Grain research and Development Corporation 2017. Northern Faba Bean-Best Management Practices Training Course. Pulse Breeding Australia 2014. February 2017.

[21] Williams, W., 1985. Genetic Improvement of Grain Protein Crops- Achievements and Prospects. Pp. 63-84. In: G. E. Russel (ed.). Progress in Plant Breeding-1. Buttermworth \& Co. (Publishers) Ltd, London, Boston, Durban, Singapore, Sydney, Toronto, Wellington.

[22] Elsheikh, E. A., Eltinay, A. H., Fadul, I. A. (1999). Effect of nutritional status of faba bean on proximate composition, antinutritional factors and invitro protein digestibility (IVPD). Food chemistry. 68: 211-212.

[23] Abdulrahim, S. I (2004). Effect of soaking, cooking, dehulling and germination on anti-nutritional factors and IVPD of faba bean (Vicia faba). MSc. Thesis, Faculty of Agriculture, University of Khartoum, Sudan.

[24] Centro Internacional de Agricultura Tropical (CIAT), 1993. Bean Program Annual Report. Working Document No. 161, 1996, Cali, Colombia. Pp. 6-13.

[25] Picard, J. 1977; Some results dealing with breeding protein content in Vicia faba L. Protein quality from leguminous crops; EVR 5686 EN, Commission of European Communities, Coordination of Agricultural Research: $p$ 339 .

[26] Chavan JK, Kute LS, Kadam SS 1989. Broad bean. In: Handbook of world food legumes: nutritional, processing, technology and utilization, vol I. CRC Press, Boca Raton, Fl, pp 223-245.

[27] Ramakrishna, V., Jhansi Rani P. and Ramakrishna Rao P., 2006. Anti-Nutritional Factors during Germination in Indian bean (Dolichos lablab L.) Seeds, World Journal of Dairy \& Food Sciences 1 (1): 06-11.

[28] Fatemeh E, Allen V. B, Masoud H, Omid R. Zi, and Yeonhwa P. (2018), Nutrient accumulation in faba bean varieties Article in Communications in Soil Science and Plant Analysis July 2018. 
[29] Ebthag Awad Allah Mohamed Osman Ali, Amir Mahgoub Awadelkareem, Seif Gasim, Nabila El Amir Yousif (2014), Nutritional Composition and Anti Nutrients of Two Faba Bean (Vicia Faba L.) Line, International Journal of Advanced Research, Volume 2, Issue 12, 538-544.
[30] Walsh (1963), Factors affecting the availability of nutrients to plant. In Wash and Beata 1963 J. D. Editors Soil testing and plant analysis pp. 23-33, Madson Soil Science Society of America. 